\title{
GENERATING PRESS, BOLD IDEAS, AND STUBBORNNESS: THE IMPACT OF CELEBRITY CEOS
}

\author{
Shellby J. Solomon \\ Louisiana State University • Baton Rouge, LA \\ Joshua Bendickson \\ University of Louisiana at Lafayette • Lafayette, LA
}

\section{ABSTRACT}

Our purpose is to investigate and discuss the impact of celebrity CEOs. Numerous CEOs have attained celebrity status through infusion into media coverage. Consequently, CEOs routinely enter into American popular culture. We offer general propositions that successful CEOs gain positive media coverage, and thus gain celebrity CEO status. Subsequently, celebrity CEOs are vulnerable to becoming rigid in their business strategy and also fixate on increasing firms' corporate social responsibility operatives, both of which are enhanced by narcissism. Under negative conditions (i.e., poor performance, bad press), celebrity CEOs tend to escalate their commitment as opposed to admitting a change is necessary.

Keywords: Celebrity CEOs; media coverage; narcissism; escalating commitment

\section{INTRODUCTION}

Chief Executive Officer (CEO) research and theory has primarily focused on how the characteristics, values, schemas, and ownership of CEOs relate to organizational outcomes (e.g., Angriawan \& Abebe, 2011; Daily \& Dalton, 1992; Hambrick \& Mason, 1984; Hayward \& Hambrick, 1997). This stream of research formally known as upper echelons theory has been successful in demonstrating how CEO attributes (e.g., personality or tenure) affect organizational strategies (e.g., Chatterjee \& Hambrick, 2007; Miller, 1991). The study of CEO attributes in relation to organizational outcomes represents a promising avenue to conceptualizing how modern media attention and the process of a CEO becoming a celebrity may affect a firm's business strategy. Furthermore, news stories about CEOs have been on a steady rise in popularity within American news media (Park \& Berger, 2004). Yet throughout the course of CEO studies, researchers have neglected to offer neither a composite description of how celebrity and non-celebrity CEOs may differ in business strategy nor a definitive conclusion as to what extent the firm and CEO share the benefits (or detriments) of celebrity status. Moreover, relatively few studies 
of upper echelons theory investigate the effects of celebrity status on firm level outcomes (Treadway, Adams, Ranft, \& Ferris, 2009).

To address these gaps in the research we conducted an extensive review of the literature regarding celebrity CEOs with the goal of identifying underlying themes of celebrity CEO behavior and firm strategies. As a result of our effort we are able to offer a model that better conceptualizes how the celebrity status of a CEO affects the specific strategies that are pursued by the CEO. Additionally, we are able to make the general conclusion that celebrity status disparately affects both the CEO and firm level outcomes. Specifically, we determine the general trend that CEOs are most often positively rewarded for their celebrity status while the firms employing the celebrity CEOs receive a mix of positive and negative outcomes.

To understand the implications of CEO celebrity status, we first explain a CEO's impact on the firm. This is accomplished through a brief examination of the literature regarding upper echelons theory. Second, we delve into the process and antecedents of how a CEO becomes a celebrity. Third, we look into the possible effects that celebrity status has on a given CEO's strategic decision-making ability. Additionally, we offer testable propositions regarding the possible outcomes of a celebrity CEO's decisions and how they might differ from a non-celebrity CEO. Finally, we identify the implications for future research, the limitations, and the conclusion.

\section{UPPER ECHELONS THEORY}

A CEO, in some ways, is comparable to the captain of a ship. A ship's captain may not actually own the ship and may not be the one in charge of selecting the ultimate destination that the ship is traveling toward. However, in the short run, a ship's captain is in charge of how the ship makes the trip to a specified destination. This allows a captain some autonomy in exercising their judgment in choosing the best course of travel. Therefore, how the ship operates on its trip to a specified destination is a direct manifestation of the captain's decisions. Although, a CEO may not be the owner of the firm and is assigned the goal of creating wealth for the shareholders, the CEO still has the ability to control the direction of the firm in the short run and is allowed to use their best judgment in determining the most suitable course.

The notion that a firm will be a reflection of the firm's dominant coalition or top management has been in existence for a long time. For example, agency theory can be viewed as largely economics based relative to upper echelons theory. A link 
between agency theory and upper echelons theory exists because agency theory states that the manager in charge of a firm may act in a self-interested fashion, which is often detrimental to the owner of a firm (Jensen \& Meckling, 1976; Nyberg, Fulmer, Gerhart, \& Carpenter, 2010). Therefore, if a manager has the ability to behave in a self-interested fashion and influence the strategy of the firm, it would appear that the strategy of the firm is directly related to the CEO's motivations. However, agency theory only states that a CEO will act in such a way that benefits their personal motives, and typically assumes that monetary wealth creation is the driver behind all actions.

It was not until nearly a decade after agency theory rose to prominence that the concepts from organizational behavior, psychology, sociology, and strategic management would be combined to form upper echelons theory (Hambrick \& Mason, 1984). Upper echelons theorists seek to go beyond the assumption of selfinterest to identify the origins of managerial motives, which makes the perspective distinct from the economics based view associated with agency theory. According to the seminal work in upper echelons theory, a firm's strategic maneuvers are a function of managerial perceptions (Hambrick \& Mason, 1984). Using perceptions as the determinate of behavior requires that scholars must take into account the personal characteristics of the beholder, because perceptions by definition include a level of subjectivity. Therefore, according to upper echelons theory, one may predict that personal characteristics, relationships, properties, and demographics such as experience, race, age, values, and education, along with bounded rationality combine to form a perception of reality which is used to make a strategic choice (Hambrick, 2007; Hambrick \& Mason, 1984). One example of how a CEO's personal characteristics affect their behavior can be observed in a CEO's tenure. Past research has shown that across firms with long tenured CEOs, there is less change in strategy than in firms with short tenured CEOs (Miller, 1991). Furthermore, CEO impact has been supported through research, demonstrating that firms in which a CEO has recently been replaced, experience a higher degree of change in firm strategy than those firms that have not recently replaced a CEO (Boeker, 1997). In the current paper we take into account the implications of upper echelons theory and propose that celebrity status can affect a CEO's behavior. Ultimately, the effects of celebrity status on a CEO will be manifested in a unique set of firm level outcomes. The effects of celebrity status on CEO and firm level performance are further discussed in the following sections and an overview of the model is provided in Figure 1. 


\section{Figure 1. \\ Summary of Propositions*}

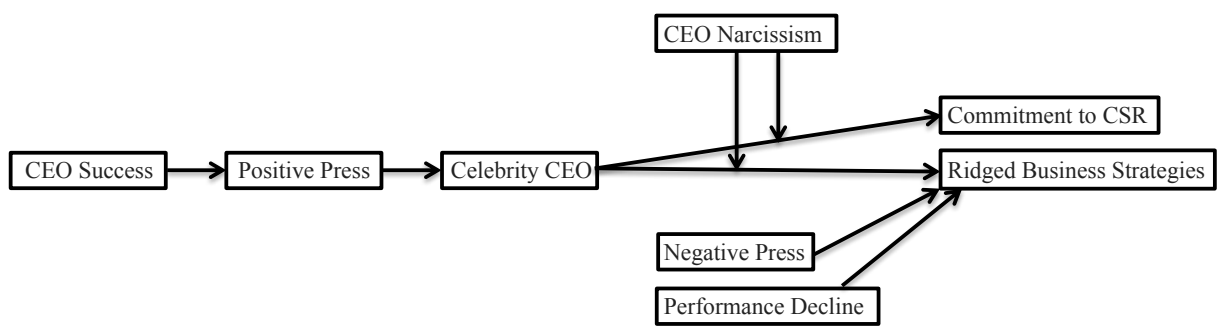

*All relationships included within the model are theorized to be positive

\section{THE PROCESS OF BECOMING A CELEBRITY CEO}

The term celebrity is a commonly used but not always entirely understood by the general public, and can easily be confused with reputation by the layperson. The notion of "celebrity" is a construct that was developed outside of the management literature and originates in the field of mass communication (Treadway et al., 2009). A classical definition of celebrity is: a social actor who is able to favorably capture the attention of the masses in such a grand fashion that their notoriety has the ability to be a profit generating resource (Gamson, 1994; Rein, Kotler, \& Stoller, 1987). More recently celebrity has been conceptualized as, "a property of the actor's relationship with an audience, rather than a characteristic of the actor him/her/itself" (Rindova, Pollock, \& Hayward, 2006: 52). Taking this view of celebrity into account, celebrity can be seen as an intangible asset very similar to goodwill, which is often (yet not always) a positive attribute.

The process from which a celebrity arises requires a certain set of antecedents (Hayward, Rindova, \& Pollock, 2004; Treadway et al., 2009). For a CEO to draw the attention of popular culture and reach celebrity status, the CEO must first be successful enough to differentiate themselves from the common crowd of business professionals, and demonstrate a degree of consistent and distinct action and behavior (Hayward et al., 2004; Treadway et al., 2009). The combination of success and distinct personal attributes makes it possible for the CEO to be represented to the public as a unique "character" or "celebrity." For example, Steve Jobs first built a successful computer company, however, he was distinct from other business professionals because he embraced his persona as a free spirit who would wear 
sandals, travel to India for spiritual retreat, and even admit to experimenting with drugs. Additionally, Jobs demonstrated a high degree of consistent behavior through his commitment to innovation, intuitive design, and quality. Furthermore, he fostered his relationship with the media through engaging in highly publicized product releases. Consequently, one may observe how he became a successful businessman and how he also behaved in a fashion that showcased his unique persona, thus meeting the previously mentioned antecedents. This makes Jobs a prime example of a celebrity CEO.

Media coverage is typically viewed as a strong correlate of one's level of celebrity (Park, Kim, \& Sung, 2014), and this aspect is important because journalists are under social and financial pressure to publish stories that meet the public's demands (Darnton, 1975; McQuail, 1985; Nimmo \& Sanders, 1981). However, media coverage has a unique bias which serves to further propagate a celebrity's unique persona. Media coverage is often guilty of dramatizing reality to build a story that is complete and in turn, interesting to viewers (Andreassen, 1987; McCartney, 1987; Rindova et al., 2006). Hence, the news and media may cater to the public's need for entertainment at the expense of their desire for information. This bias is manifested in the news coverage of CEOs. The news is known to portray CEOs as protagonists (or antagonists) who are similar to characters in a story that possess defining characteristics. These tendencies over emphasize the uniqueness of a given $\mathrm{CEO}$, and give little attention to the more common attributes of the CEO. This bias also takes form in a second type of attribution error whereby the media credits the CEO's unique capabilities as the cause for the organization's success, rather than the significance of the other more ambiguous sources (Hayward et al., 2004). Thus, in an attempt to explain a firm's success, the media can take a CEO, who is somewhat distinct, and portray him/her as being an extremely idiosyncratic individual who is entirely responsible for the organization's success. This process then generates public interest in the CEO and a cycle of celebrity may be put into action.

In addition to success, distinctive action, and the tendencies of the media, becoming a celebrity CEO also involves how CEOs respond to the media attention. In the past, firms such as Wendy's, Apple Inc., Martha Stewart Living, and Chrysler have used their CEO as a spokesperson in an attempt to draw in the public's attention. Other business personalities have entered on to television shows such as Shark Tank, The Apprentice, and Undercover Boss for perhaps similar reasons. The rationale for a CEO to desire celebrity status can be in part explained by the conceptualization of celebrity as a profit-generating attribute of a social actor (Rindova et al., 2006). A second rationale for corporate conformity is institutional pressure (DiMaggio 
\& Powell, 1983). Due to the conceptualization of success and differentiation as the antecedents of celebrity, business professionals of modest success may want to be perceived as being successful, and therefore seek the public's attention. The result of this isomorphic pressure pushes CEOs to seek media attention and further incentivizes CEOs to aim to achieve celebrity status.

Proposition 1a: Successful CEOs will attract positive attention from the media.

Proposition 1b: Positive attention from the media will enhance CEO celebrity status.

\section{CELEBRITY CEO STATUS AS A CAGE}

If we accept the premise that human actors are supposed to exercise rationality, then a $\mathrm{CEO}$ who remains ridged in her strategy and conforms to her celebrity image in the face of failure, presents an anomaly. Though Rindova et al. (2006) discuss celebrity as a profit generating intangible asset; there are times when a CEO will face the decision of whether or not to break character in order to seize an opportunity or to avoid a threat. At such times, the costs of character rigidity can offset the returns of celebrity. Taking into account the assumption of bounded rationality, the CEO will hold character only if she believes it to be the best course of action. The aim of this section is to take a look at why a CEO might place such high trust in him/herself and value character rigidity and celebrity; even when it may not appear to be the most efficient decision. To facilitate the advancement of the celebrity CEO literature, we have also provided a thorough overview of the celebrity CEO literature as positioned relative to our research. Please see Table 1 for a systematic review of relevant research based on a keyword search of the Discovery database. In order to conduct a thorough exploration of the literature we searched for articles that contained (in the abstract) any combination of the word CEO along with celebrity, media coverage, media attention, press coverage, press attention, or narcissism. The search yielded a list of 109 scholarly peer reviewed articles. We then combed through the results of the search for any articles that were directly related to the present manuscript. That is, we selected articles for inclusion in our literature review if the articles concerned the topic of celebrity CEOs or CEO media coverage and how the celebrity status/ media coverage affected the $\mathrm{CEO}$ or firm. 


\begin{tabular}{|c|c|c|c|c|}
\hline \multirow{9}{*}{ 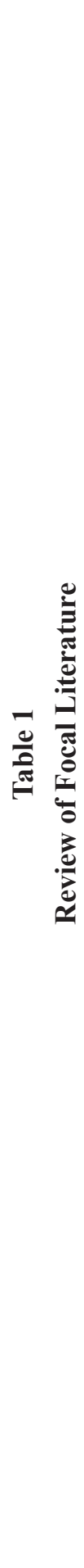 } & 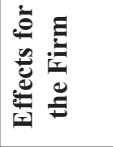 & $\begin{array}{l}\stackrel{0}{+} \\
\stackrel{0}{0} \\
\frac{0}{2}\end{array}$ & 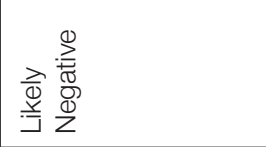 & \\
\hline & 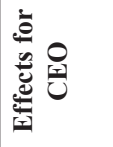 & 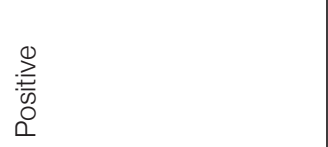 & 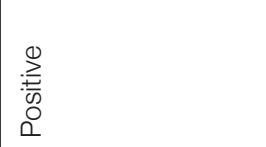 & $\underset{\substack{\infty \\
0 \\
0 \\
0}}{0}$ \\
\hline & 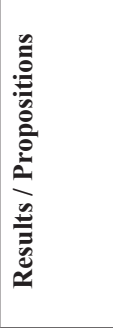 & 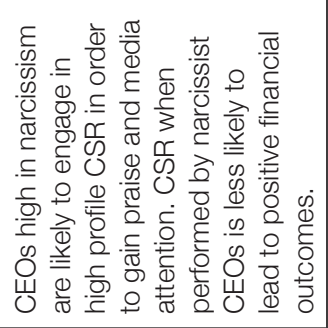 & 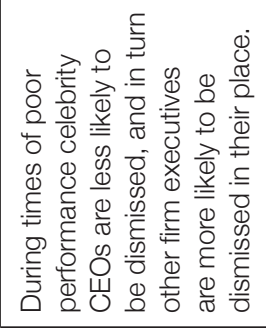 & 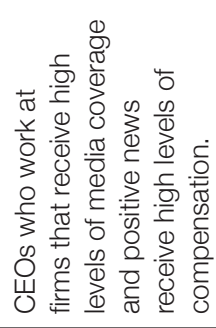 \\
\hline & 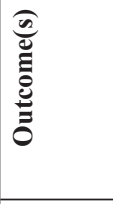 & 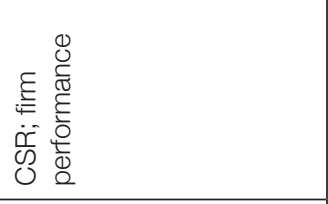 & 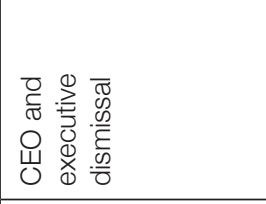 & 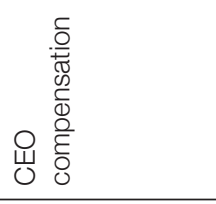 \\
\hline & 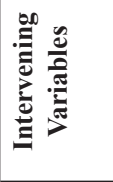 & & 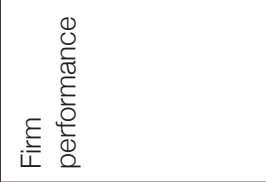 & \\
\hline & 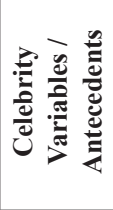 & 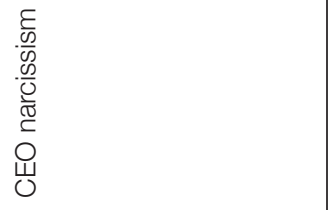 & 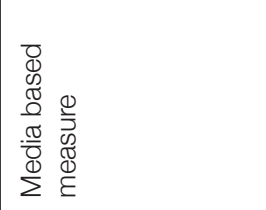 & 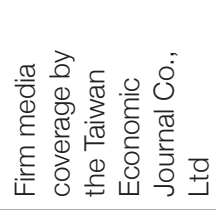 \\
\hline & 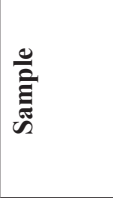 & 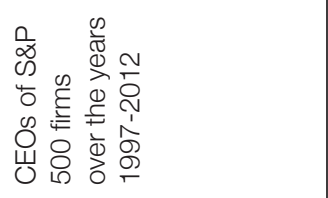 & 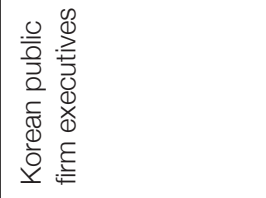 & 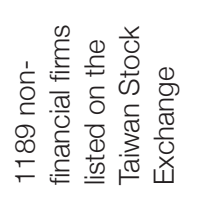 \\
\hline & 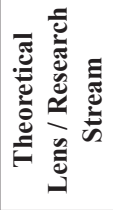 & 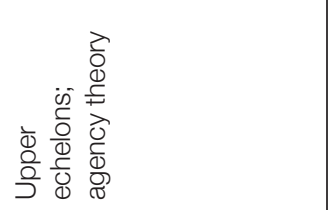 & 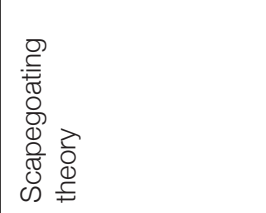 & 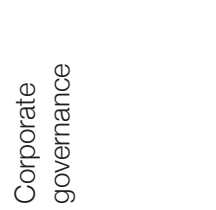 \\
\hline & 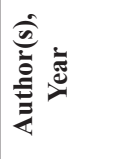 & 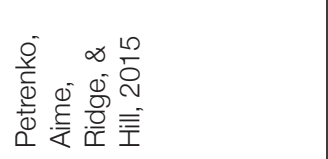 & 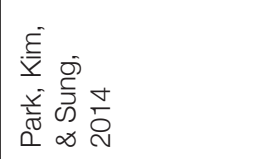 & 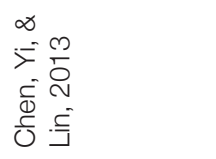 \\
\hline
\end{tabular}




\begin{tabular}{|c|c|c|}
\hline & 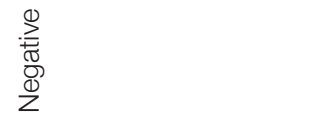 & 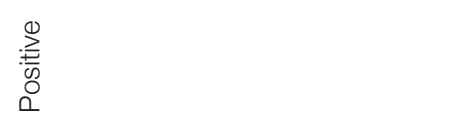 \\
\hline \multicolumn{3}{|l|}{ 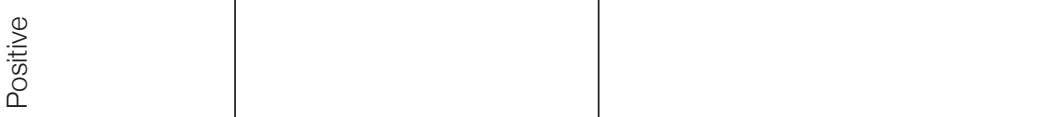 } \\
\hline 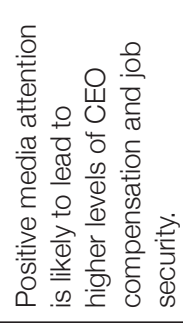 & 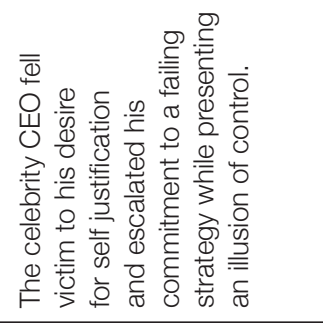 & 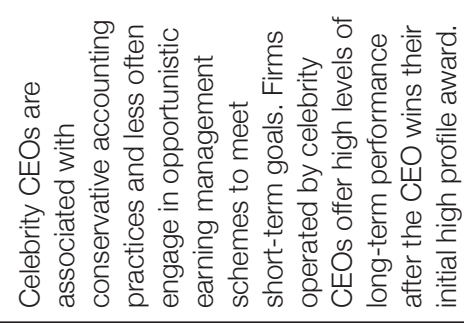 \\
\hline 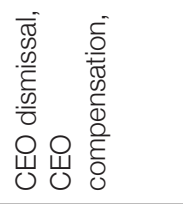 & 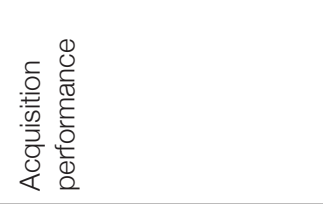 & 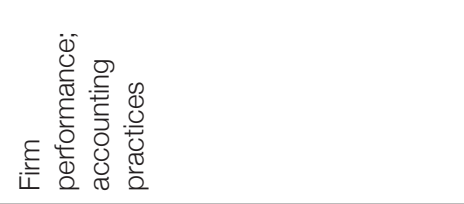 \\
\hline & 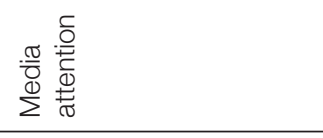 & \\
\hline 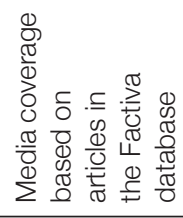 & 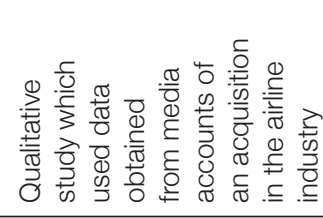 & 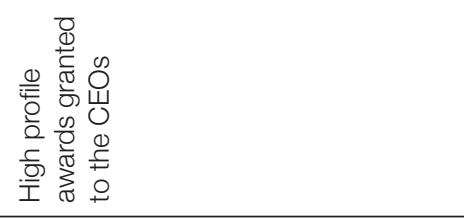 \\
\hline 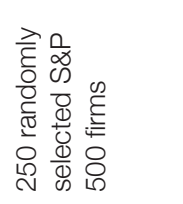 & 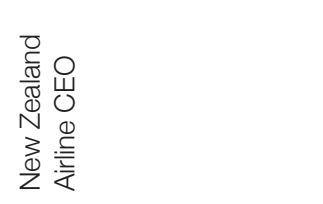 & 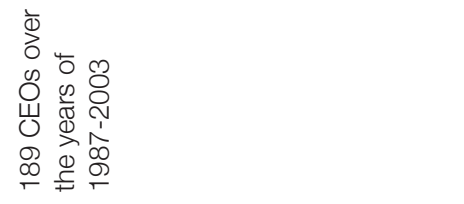 \\
\hline 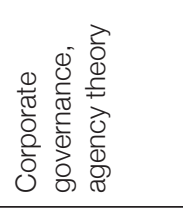 & 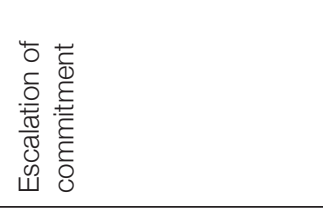 & 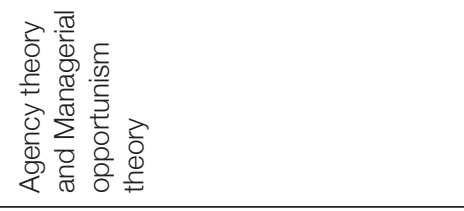 \\
\hline 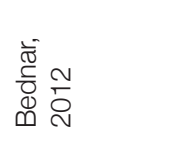 & 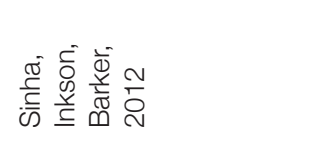 & $\begin{array}{l}\bar{\sigma} \\
\overline{2} \\
\bar{c} \\
\underline{2}\end{array}$ \\
\hline
\end{tabular}




\begin{tabular}{|c|c|c|}
\hline & & $\begin{array}{l}\stackrel{0}{\infty} \\
\stackrel{0}{0} \\
0\end{array}$ \\
\hline & $\begin{array}{l}\overline{\widetilde{\sigma}} \\
\stackrel{+}{5} \\
\frac{0}{Z}\end{array}$ & \\
\hline 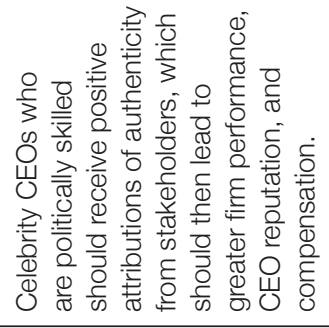 & 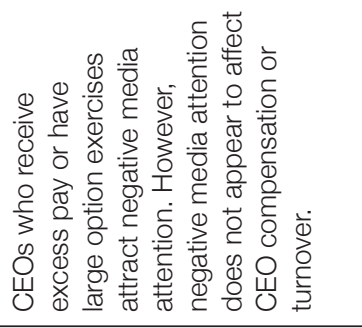 & 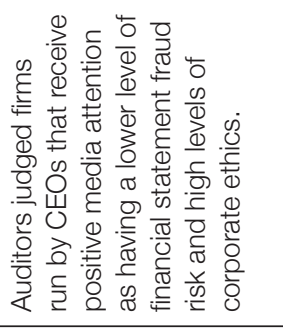 \\
\hline 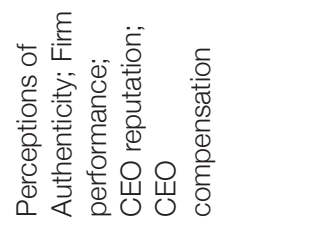 & 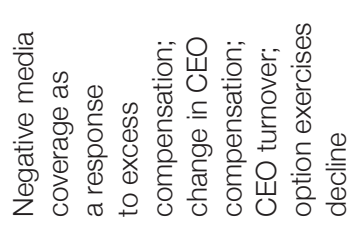 & 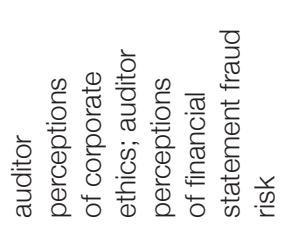 \\
\hline 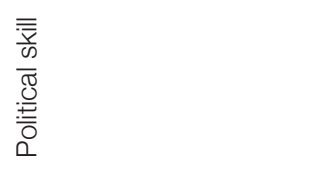 & & \\
\hline 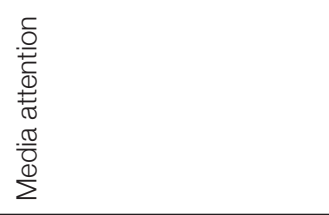 & 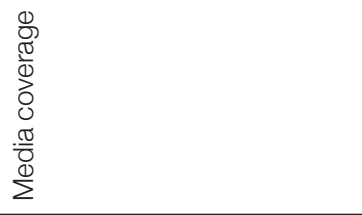 & 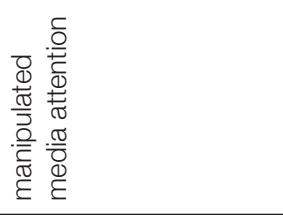 \\
\hline 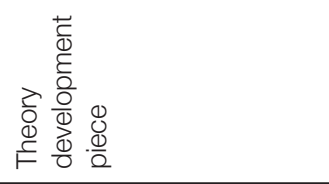 & 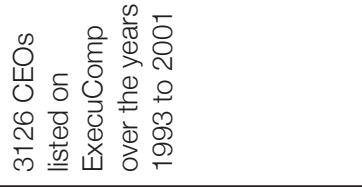 & 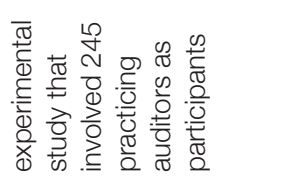 \\
\hline $\begin{array}{l}\frac{0}{\bar{E}} \\
\frac{\infty}{\frac{1}{0}} \\
\frac{\Phi}{8} \\
\Phi \\
\Phi\end{array}$ & $\begin{array}{l}7 \\
0 \\
0 \\
+ \\
+ \\
0 \\
0 \\
\frac{1}{0} \\
\frac{7}{4}\end{array}$ & 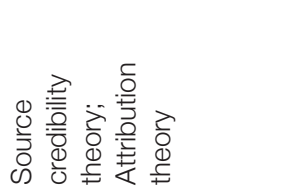 \\
\hline 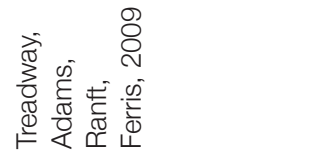 & 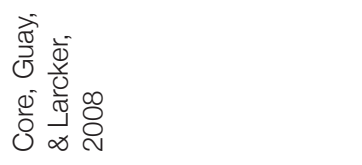 & 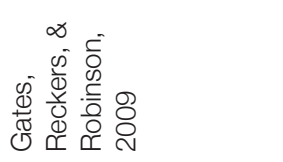 \\
\hline
\end{tabular}




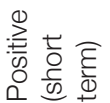

$\stackrel{(1)}{2}$

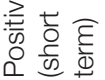

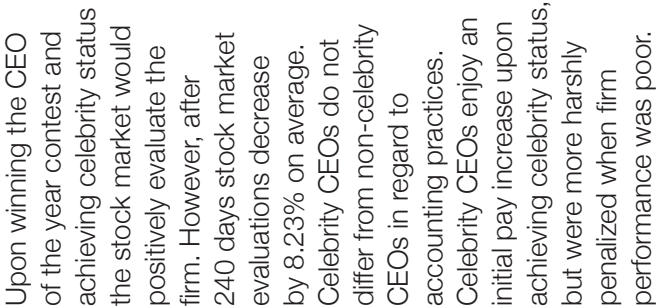

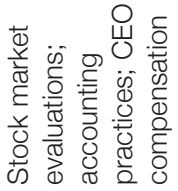

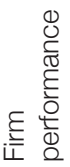

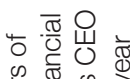

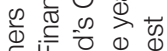

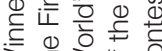

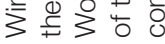

$\stackrel{\infty}{\sim} \underset{\sim}{\stackrel{\infty}{=}}$

प⿺辶

岁

ำ

을 중

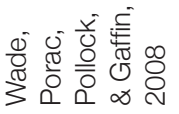




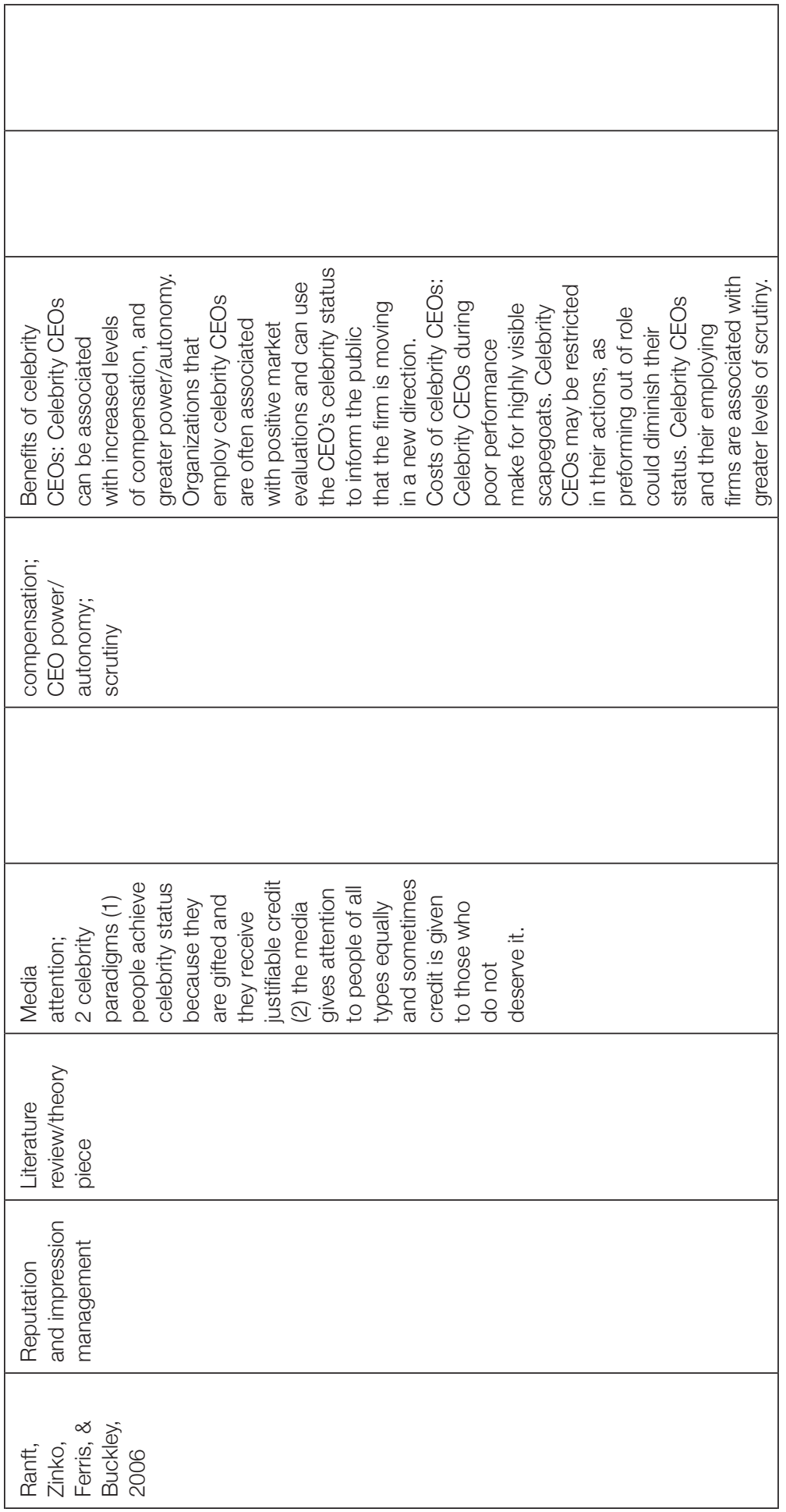




\begin{tabular}{|c|c|}
\hline & $\S$ \\
\hline & 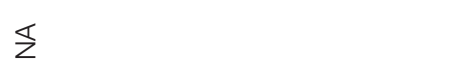 \\
\hline 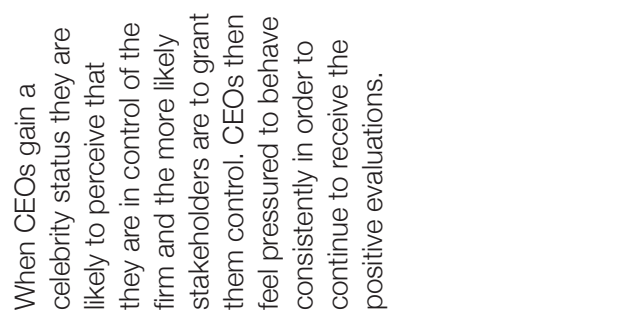 & 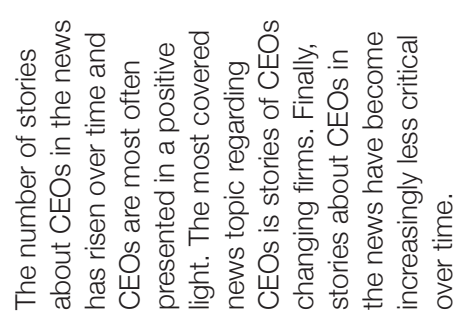 \\
\hline 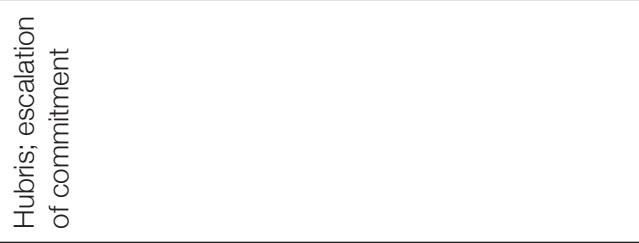 & 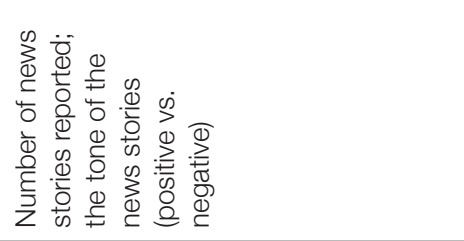 \\
\hline 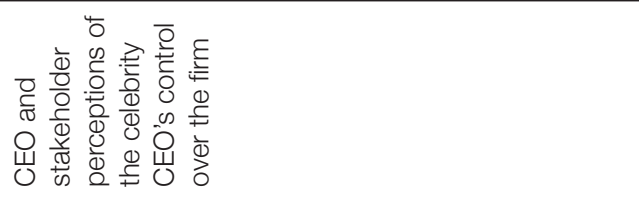 & \\
\hline 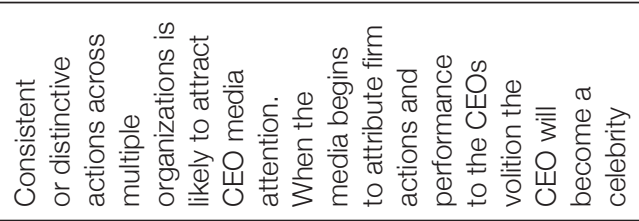 & 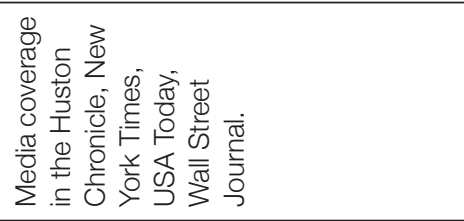 \\
\hline 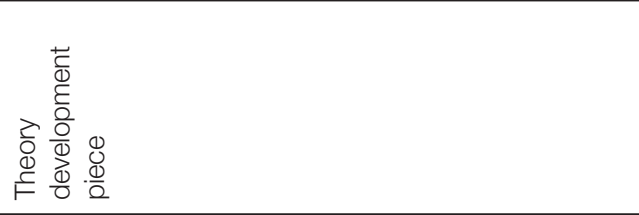 & 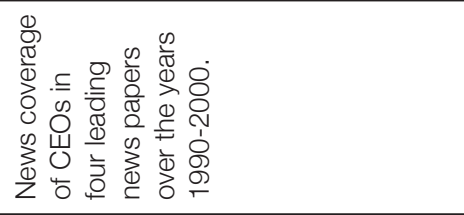 \\
\hline 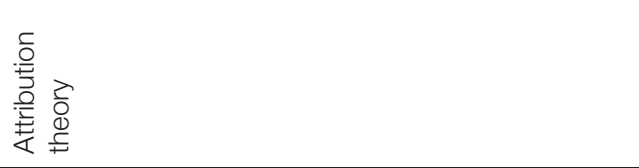 & $\begin{array}{l}\frac{7}{0} \\
\frac{0}{\pi} \\
\frac{0}{0} \frac{7}{0} \\
\frac{0}{\frac{1}{2}}\end{array}$ \\
\hline 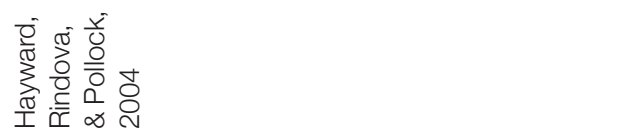 & 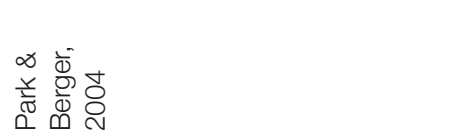 \\
\hline
\end{tabular}




\section{The hot hand fallacy}

CEOs may be separated from the general public by a wide economic and business status margin. However, CEOs are still humans and like other humans, they are vulnerable to the same fallacies and pitfalls of their needs and cognitive abilities. First, consider the antecedents of celebrity status which are success and the level of consistent uniqueness that differentiates the celebrity $\mathrm{CEO}$ from the general population of CEOs (Hayward et al., 2004; Treadway et al., 2009). Consequently, CEOs reaching celebrity status are often known for particular characteristics or strategies that can be partially attributed to their success. It has long been an assumption of human nature that people have a desire to find the causes of different outcomes (Heider, 1958). In the case of celebrity CEOs, the media reinforces the relationship between the CEO's idiosyncratic personal traits and their success, by dramatizing the reality of the situation to increase public interest in the topic (Andreassen, 1987; McCartney, 1987; Rindova et al., 2006). Additionally, previous laboratory studies have been conducted to investigate the bias of success being most frequently attributed to leaders. A classic laboratory study of attributional bias involved a sample of undergraduates who were asked to read an unbiased vignette which described an organization and its performance (Meindl, Ehrlich, \& Dukerich, 1985). The findings of the study supported the hypothesis that people have a bias toward attributing the performance of an organization to that organization's leader. Meindl et al. (1985) theorize that this phenomenon is a cultural preference. Therefore, we as a culture tend to favor the dramatic story of a heroic leader, rather than a complex interaction of people and inputs when determining the causes of success. The increased level of success experienced by a CEO, compounded by the positive press, can have negative effects on a CEO's future performance. The negative effects can come in the form of hubris traps and pitfalls as a result of one's inflated ego.

Gilovich and colleagues' past research has demonstrated one example of a hubris trap called the "hot hand effect" (Gilovich, Vallone, \& Tversky, 1895; Tversky \& Gilovich, 1989). The hot hand effect is a term popularly used by athletes and sports fans to describe a performance streak. According to the premise of the hot hand effect, one is more likely to achieve a successful outcome, such as making a basket while playing basketball, if they had previously made several baskets in a row. To examine this phenomenon, Gilovich et al. (1985) studied both the performance of a professional basketball team and the attitude of the players and fans toward the hot hand effect. They found that both the players and fans believed that the hot hand effect was true and that players who made several baskets in a row were more 
likely to make subsequent shots. However, the performance results did not provide any supporting evidence for the hot hand effect. Hence, a streak of success does not necessarily breed future success, but can lead one to have an inflated view of their self-efficacy or ability to successfully engage in a particular task.

The competency trap, known as the "hot hand effect," represents a pattern of behavior where initial success inhibits an individual from making adaptive strategic decisions. This idea is replicated in both the organizational learning literature and in the upper echelons literature regarding CEO tenure (Levitt \& March, 1988; March, 1991: Miller, 1991). In organizational learning researchers have commonly asserted that a string of successes can lead individuals (within a firm) to stop engaging in experimentation and become rigid to a set of processes. The result of the rigidity associated with success is ultimately expected to lead to organizational decline, as the firm will not have gained the necessary knowledge by undergoing the experimentation needed to adapt to environmental change. Within the literature regarding upper echelons, Miller (1991) found that CEOs typically start out employing a broad range of strategies, but over time restrict themselves to those strategies that have been successful in the past.

The "hot hand effect" could be interpreted and generalized, regarding CEOs and basketball players alike, in the business environment as: leading people to believe that their success is unlikely to fluctuate in the short term (Gilovich et al., 1985). Similar to tossing a coin or spinning a roulette wheel, there is a chance that one will experience a duration in which he/she correctly selects the outcome on numerous consecutive occurrences. However, each of these outcomes is an independent event and it is only by chance they have fallen in a row. In the context of a celebrity CEO, they have likely achieved celebrity status by riding a string of successes to the top and have captured the public's attention. The CEO's streak of success is then likely to be further exaggerated by the press' attribution of firm success to the CEO (Andreassen, 1987; McCartney, 1987; Meindl et al., 1985; Rindova et al., 2006). This scenario can set a CEO up to believe they possess the "hot hand." Therefore, the CEO may become involved in an increased number of subsequent endeavors, because their ego has become inflated by a combination of the previous success streak and the public's attention crediting the success of the organization to the celebrity CEO.

Conversely, the subsequent endeavors are likely to be even more failure prone than the previous endeavors, because the general public and press may falsely attribute the success to the actions taken by the CEO and therefore fostering hubris. Unlike in the hot hand effect study, where the players who made the basket received the credit, the cause of success and attribution of credit may be decoupled in a firm 
setting (Gilovich et al., 1985). The likelihood of decoupling the events leading up to the success and the attribution of credit for the success will be magnified if the CEO is a celebrity. The decoupling will occur because the celebrity CEO will attract the attention of the media, which has a bias to dramatize events in a simplistic fashion that typically romanticizes the $\mathrm{CEO}$ as the hero so that the public's demands are met. Therefore, once a CEO becomes a celebrity they may falsely receive positive feedback. That is, a firm's success clearly cannot all be attributed to the CEO, yet the CEO is the one who is most likely to receive the credit. A situation where the cause and credit for success are decoupled may lead a CEO whose actual success rate is in a slow decline, to believe that he/she is on a hot streak and should engage in more endeavors. The subsequent undertakings will now be a function of the CEO's declining success rate and will be less likely to succeed, than activities initiated by the more successful departments of the firm. Moreover, the celebrity CEO similar to the basketball player will continue to use the same technique which resulted in their initial success, but they will now be emboldened to employ it more liberally and with greater confidence. For the celebrity CEO, this may result in a myopic strategy that misses possible opportunities and is vulnerable to environmental shifts.

An additional laboratory study related to the hot hand effect was that of Hilary and Menzly (2006), which found that analysts who had a streak of successful investments were more likely to become overconfident in their abilities. The overconfidence was found to be a temporary phenomenon and its duration was a factor of the level of success and the length of the streak. When the findings of Hilary and Menzly's (2006) study are applied to the CEO position of a firm, the risk of overconfidence becomes multiplied. This overconfidence or hubris will result because the celebrity CEO is given credit for great success even when their inputs may have been modest, so long as the firm is successful as a whole (Andreassen, 1987; McCartney, 1987; Meindl et al., 1985; Rindova et al., 2006). Moreover, combining the implications from the previous hot hand studies with studies which indicate that hubris and overconfidence lead to paying higher acquisition premiums (Hayward \& Hambrick, 1997), we conclude that CEOs who engaged in the overpriced acquisitions likely did so because they were successful in previous acquisitions and now have subscribed to a static strategy based on a previous success streak.

A stream of literature that is related to the hot hand effect is that of escalation of commitment. The research on escalation of commitment offers a convergent set of predictions in describing how a celebrity CEO can become locked into a rigid course of action (Staw, 1981). Escalation of commitment refers to situations where individuals face adversity and instead of yielding to the adversity at a certain point 
to cut their losses, they expend more resources in an attempt to conquer the obstacle. Furthermore, prior research indicates that people are likely to filter out some of the criticism when making wrong decisions (Salancik \& Kiesler, 1971). Therefore, individuals may construe feedback in such a way that they do not see the full costs of their actions. Zajac and Bazerman (1991) theorize that overconfidence can leave one vulnerable to the competency trap of escalation of commitment. If one is feeling overconfident or arrogant, then one will be biased toward seeing fair possibilities of success, even in situations that are most likely to produce a treacherous outcome. This mental state makes the hubristic decision maker particularly vulnerable to competency traps such as escalation of commitment or the hot hand effect. In the business world, a CEO may display vulnerability to competency traps by insisting a firm remains loyal to a failing strategy. Therefore we propose the following:

Proposition 2: As CEOs gain more celebrity status, the more ridged they will become with their business strategy.

\section{Social pressures}

The previous section of this paper discussed why a celebrity CEO might employ a static business strategy. The rationale for this inefficient behavior was based on the CEO's perceived level of competency. The following section of the paper examines social pressures that are likely to persuade a CEO to become strategically static. CEOs are in a position of high visibility, because they are at the helm of the firm and in charge many aspects of a firm's decision making. Being in a position of high visibility is likely to lead CEOs to monitor and manage their impression. Previous research states that, "publicity affects impression motivation because public behaviors are more likely to be relevant to the accomplishment of one's goals than are private behaviors" (Leary \& Kowalski, 2009: 38). Therefore, as a CEO begins to attract more attention from the media, he/she will become increasingly motivated to manage impressions in order to achieve one's goals (e.g., avoiding public scrutiny). Relatedly, prior research demonstrated that when people noticed they were being watched by a security camera, they were more likely to engage in helping behaviors (Van Rompay, Vonk, \& Fransen, 2009). The findings from the Van Rompay et al. (2009) study demonstrates that when a person is in a position of visibility, they are more likely to engage in socially acceptable behaviors for reasons of impression management.

The impression management construct can be translated to the corporate level. Accordingly, if CEOs ascend to the ranks of celebrity status, then they will be 
aware that the media is watching. Once CEOs are aware of their level of publicity, they are more likely to engage in socially acceptable behaviors in an attempt to manage their impression. At this point, the celebrity CEO will have a difficult time engaging in acts which may be efficient but socially undesirable. Therefore, the result of the publicity will put the CEO in a position where some courses of action will no longer be an option. Additionally, the publicity will require a firm to take a relatively static stance on other socially approved actions. McGuire (1963) discusses how the actions of a firm and an individual are similar to one another; that as part of a CEO's duty to a firm, he/she must behave in a way that is respectful to society. Hence, one measurable outlet of socially approved actions that a CEO may take is to engage in acts of corporate social responsibility. For example, a firm run by a relatively unknown CEO would be less likely to engage in corporate social responsibility behaviors because she would not experience the same degree of exposure and perceived social pressure as a result of press coverage (as would a firm run by a celebrity CEO). Accordingly, we develop the following proposition.

Proposition 3: As CEOs gain more celebrity status, the more committed they will become with regard to corporate social responsibility.

\section{Narcissism}

Another issue that can lead CEOs to overconfidence and strict adherence to their strategy involves dimensions of a CEO's personality. Narcissism is a trait characterized by an inflated image of one's self, self-love, and a desire for recognition (Kernberg, 1989). Narcissists are understood to be undesirable to work with and arrogant (Buffardi \& Campbell, 2008; O’Boyle, Forsyth, Banks, \& McDaniel, 2012). Additionally, narcissists are known to have a belief that they are the only one whom they can rely on and believe that their ideas and needs are superior to all others. Therefore, narcissists have a self-centered outlook in which they do not behave in the best interest of the group, but rather are most interested in acting in accordance with their goals and desires (Kets de Vries \& Miller, 1985). A CEO who is high in narcissism will then be characterized by a disregard for the input of others and an adherence toward their strategies exclusively. This will serve to bind the CEO to a limited number of strategies based on their ingenuity and will not allow the CEO to use the advice of others to create a truly dynamic strategy. Though the verdict is unclear as to whether or not narcissism is a more commonly displayed trait in CEOs rather than in the general population (Chatterjee \& Hambrick, 2007), narcissism is applicable to the topic of celebrity CEOs. 
Past research found that a defining attribute of the narcissistic CEO is that they prefer dramatic strategic decisions that offer the possibility of high returns as opposed to a more intermediate route (Chatterjee \& Hambrick, 2007). These strategies are designed to capture the attention of the business community and public, so that the narcissist may obtain desired time in the spotlight. These risky strategies are likely to be successful on occasion, at which point the narcissistic CEO will succeed in receiving attention from the business community and perhaps even the media. In addition to preferring bold strategies, the narcissistic CEO has also been found to engage in high profile corporate social responsibility (CSR) activities at a higher rate than other CEOs (Petrenk, Amie, Ridge, \& Hill, 2015). The narcissistic CEO is likely to engage in CSR in order to capture the attention of the media and public as opposed to more genuine motives associated with creating social welfare. Hence, a strong commitment to CSR and other highly visible displays of ethics may also be a tactic used by the narcissistic CEO to gain the positive attention that they desire.

Once in the public spotlight a narcissistic CEO is likely to be better able to maintain a prominent position in media coverage because of the strong self-promotion characteristic of a narcissistic personality (Buffardi \& Campbell, 2008). As discussed previously, the antecedents of celebrity status are both success and uniqueness. Therefore a self-promoting, narcissistic CEO who has recently experienced success through the use of a risky and audacious strategy and/or is known for highly visible displays of CSR, will be in a position to achieve greater celebrity status. Additionally, one can expect the process of operant conditioning or the notion that organisms will repeat behaviors which previously produced a desired outcome, will have an effect on the future behavior of the narcissistic CEO. If the CEO is able to achieve celebrity status through a combination of recognition, for the use of a daring business strategy and self-promotion, then it becomes possible for a static pattern of behavior to occur. In accordance to the theory of operant conditioning, once a narcissistic CEO has been able to successfully gain and maintain the attention of the press, it is expected that the CEO will continue to use such bold strategies. This will result in the newly created celebrity/narcissistic CEO learning that the use of bold strategies is a viable action for achieving access to fame and praise (Ferster \& Skinner, 1957).

In addition to providing the CEO with desired levels of media attention, CEOs are financially incentivized to continually generate positive media attention as positive media attention is often linked to desirable CEO outcomes, such as increased job security and greater compensation (Bendar, 2012; Chen, Yi, Lin, 2013; Park et al., 2014). Hence, one may rationalize that positive media attention can help the CEO to gain notoriety in the external job market and allow the CEO 
to have a powerful bargaining position during talks of compensation. The CEO can also take advantage of favorable attribution errors and hold the other executives accountable for mistakes. Therefore, a narcissistic/celebrity CEO will most likely employ strategies that play to the media, as such strategies are more likely to satisfy the CEO's need for attention and monetary rewards more effectively than dynamic strategies that focus strictly on helping the firm and producing reliable market gains. Hence, the following propositions are offered.

Proposition 4a: Narcissism will positively moderate the relationship between CEO celebrity status and ridged business strategies

Proposition 4b: Narcissism will positively moderate the relationship between CEO celebrity status and the commitment to corporate social responsibly.

\section{CELEBRITY CEO REACTIONS TO NEGATIVE PERFORMANCE AND NEGATIVE PRESS}

In addition to our theoretical model, we also weigh in on $\mathrm{CEO}$ reactions to negative outcomes. As noted previously, CEOs are in a position of both leadership and visibility in regards to the firm they serve. Moreover, CEO's actions are subject to their attitudes and characteristics as described in upper echelons theory (Hambrick, 1984). Therefore, a reasonable conclusion is that CEOs will follow the same set of norms that are subscribed to by other leaders. Additionally, celebrity CEOs will be even more visible than the average CEO, and will be subject to perform a higher degree of impression management than non-celebrity CEOs who are in a position of less visibility (Van Rompay et al., 2009).

In addition to avoiding public scrutiny for behaving in a socially undesirable fashion, there is also a degree to which leaders are expected to make correct decisions. The social pressure to succeed, though very different from the over confidence syndrome mentioned earlier, can lead to a similar process of an escalation of commitment with a focus on external justification (Fox \& Staw, 1979; Staw, 1981; Staw \& Ross, 1980). Moreover, this cycle has been supported in a laboratory setting demonstrating that when one is under pressure to succeed and/or dispute critics, they are most likely to increase their commitment to a particular course of action (Fox \& Staw, 1979). A second laboratory study by Staw and Ross (1980) found that followers have a desire for their leader to behave in a consistent manner when confronted with adversity. This desire for leader consistency was demonstrated by asking study participants to evaluate the leadership skills of hypothetical administrators. The study included conditions that varied the administrator's behaviors based on 
the use of either experimental or consistent strategies that led the administrator to either success or failure. The results of this study demonstrated that administrators receiving the highest ratings are those that employ a consistent strategy and are also successful (Staw \& Ross, 1980). A prominent rationale explaining why followers prefer leaders who behave consistently to achieve success is that the consistency demonstrates a leader's fortitude, granting them a heroic persona (Staw, 1981; Staw \& Ross, 1980).

At the CEO level, the externally focused escalation of commitment framework is likely to have effects similar to the overconfidence based escalation of commitment (Staw, 1976; Staw, 1980). However, the externally focused escalation of commitment scenario is expected to be brought on by a different circumstance. While previous success and praise is often the driver of escalation of commitment in the overconfidence scenario, poor performance and negative press favor association with the externally focused escalation of commitment scenario (Fox \& Staw, 1979; Hayward \& Hambrick, 1997; Staw, 1981). Therefore, we expect that when celebrity CEOs are facing either public scrutiny or a decline in demand, they will become more inflexible and resistant to change with the hope that the situation will turn around so they can be vindicated in demonstrating their leadership skills. Therefore, the final propositions suggest:

Proposition 5a: When a celebrity CEO's firm experiences a decline in performance, the $C E O$ will become more rigid with their business strategy.

Proposition 5b: When a celebrity CEO faces negative press regarding their current strategy, the CEO will become more rigid with their business strategy.

\section{DISCUSSION}

By drawing on upper echelons theory, personality, and organizational literatures we begin to unpack antecedents and outcomes of celebrity CEO status. It is important for researchers and practitioners alike to better understand the constructs and phenomenon that impact $\mathrm{CEO}$ behavior and what results stem from this behavior, at the executive and organizational levels. By conducting an in depth review of the literature regarding how the celebrity status of the CEO affects both the business executive and the organization, we were able to identify a trend in the pattern of benefits associated with celebrity status. Specifically, we found that CEOs are most often the primary beneficiary of their celebrity status, while organizations do not receive the same level of rewards and sometimes face negative consequences as a result of CEOs' celebrity status. The positive organizational level outcomes 
associated with CEO celebrity were also most often based on positive evaluations of the firm's accounting integrity rather than any direct link to financial performance (e.g., Gates, Reckers, \& Robinson, 2008; Koh, 2011). Alternatively, the positive outcomes attributed to CEOs often led to desirable financial rewards for CEOs (e.g., Bender, 2012; Park et al., 2013). Hence, even when the effects of CEO celebrity status benefit both the organization and CEO, one may rationalize that the executive receives a greater reward than the organization.

In addition to offering a review of the literature, we also further build theory around the effects and processes of CEO celebrity status by offering a theoretical model of how the CEO celebrity can lead to inertial organizational outcomes. We address how media press and public praise for successful CEOs is likely to lead the CEO toward celebrity status. The results of this media coverage impacts CEOs and organizations such that CEOs will likely be interested in gaining more celebrity status and prestige; and organizations will be pressured to support the ideas of celebrity CEOs. Additionally, we contribute to the upper echelons theory literature by integrating both micro and macro levels of management as advocated by Hambrick (2007). In doing so we address how celebrity CEO status is affected by the presence of individual level traits (e.g., narcissism) yet we also examine differences between celebrity and non-celebrity CEOs at the firm level in regards to the firm's strategy (i.e., competency traps). Moreover, our theoretical model is reflective of the general trend of asymmetric executive and organizational rewards in celebrity CEO research, as we describe how a CEO may reach celebrity status and then fall victim to competency traps that are harmful to firm performance. Thus, a CEO should most often be drawn toward increasing their celebrity status as by definition it relates to an array of positive personal outcomes. These positive executive level outcomes however may not always transfer over to the organization and at times can be harmful, as we have outlined in our manuscript.

\section{LIMITATIONS AND FUTURE RESEARCH}

While the scope of our paper is restricted to the effects of the CEO on firm inertia, we believe that studying CEO behavior is important to understanding relevant organizational outcomes (Hambrick, 2007). Moreover, we are limited by a lack of empirical testing, each of the propositions previously mentioned are theoretically derived and can be empirically tested. While some variables such as corporate social responsibility can easily be found in the databases such as the one provided by KLD Research and Analytics, other variables will require a degree of 
ingenuity to measure. A future study might look into the number of times a particular CEO is mentioned in the media as a proxy for CEO celebrity. Another possible measure of CEO celebrity would be to calculate a CEO's amount of airtime received on television, radio, and the average length of text dedicated to them in any form of print media. Of course, for either of these proxy measurements of celebrity status, it would be necessary for one to take into account how well the media is disseminated across the public. This would be necessary because the construct of celebrity requires a two-way relationship where a social actor is able to capture the interest of the public. Therefore, if a CEO was on a small time television program that had less than ten viewers but aired for 3 hours every night, the CEO would not rank highly as a celebrity due to their limited appeal to the public (Gamson, 1994; Rein et al., 1987).

Next, narcissism can be assessed in a number of different ways. Direct measures of narcissism include surveys such as the NPI-16 (Ames \& Anderson, 2006). Narcissism can be assessed through more unobtrusive measures as performed by Chatterjee \& Hambrick (2007). The noninvasive measure of narcissism used by Chatterjee \& Hambrick (2007) involved examining how prominent the CEO made themselves in the firm. For example, one may measure prominence in company media, relative pay discrepancies, and even the use of singular pronouns used during interviews. A critical benefit of the unobtrusive measure is that it can be applied to past CEOs, provided the researcher(s) has access to archival firm media.

Finally, in regards to financial data, many proxies exist (e.g., stock price, market capitalization, and return on assets). In manipulating the variable of decreasing demand one may identify demand shocks in the economy such as the great financial crisis of 2008. One may then longitudinally investigate if the experimental celebrity or celebrity/narcissist group performs poorly as a function of their rigid strategies when compared to a control group of non-celebrity CEOs. Additionally, the use of financial performance before and after recessions as a dependent variable could be used to investigate whether or not firms run by celebrity CEOs would be more likely to continue to invest in CSR activities in the face of economic down turn as compared to non-celebrity CEOs. The method of using recession years as a dependent variable would allow researchers to measure firm dynamism and investigate the moderating effect of celebrity CEOs. 


\section{CONCLUSION}

While celebrity status in and of itself is considered a profit-generating attribute of a given social actor; this paper proposes several scenarios where this property can lead to firm level inertia (Gamson, 1994; Rein et al., 1987; Rindova et al., 2006). In the modern business era, firms are pushed to embrace the absorption of skills and to remain strategically dynamic as to maintain a competitive advantage (Barreto, 2010; Cohen \& Leventhal, 1990; Zahra \& George, 2002). Therefore, we conclude that although celebrity status often generates profit, the cost of firm inertia is likely to offset the celebrity associated profits particularly during times when a change in strategy is needed, such as a recession. This paper was developed as a form of guidance to aide future researchers in testing the previously mentioned propositions. If a link is established between celebrity status and CEO inertia, it would challenge the validity of the age old phase stating that "all press is good press."

\section{REFERENCES}

Angriawan, A., \& Abebe, M. (2011). Chief executive background characteristics and environmental scanning emphasis: An empirical investigation. Journal of Business Strategies 28(1), 75-96.

Ames, D. R., Rose, P., \& Anderson, C. P. (2006). The NPI-16 as a short measure of narcissism. Journal of Research in Personality, 40, 440-450.

Andreassen, P. B. (1987). On the social psychology of the stock market: Aggregate attributional effects and the regressiveness of prediction. Journal of Personality and Social Psychology, 53, 490-496.

Bednar, M. K. (2012). Watchdog or lapdog? A behavioral view of the media as a corporate governance mechanism. Academy of Management Journal, 55, 131150 .

Buffardi, L. E., \& Campbell, W. K. (2008). Narcissism and social net-working web sites. Personality and Social Psychology Bulletin, 34, 1303-1314.

Boeker, W. (1997). Strategic change: The influence of managerial characteristics and organizational growth. Academy of Management Journal, 40, 152-170.

Chatterjee, A., \& Hambrick, D. C. (2007). It's all about me: Narcissistic chief executive officers and their effects on company strategy and performance. Administrative Science Quarterly, 52, 351-386.

Chen, C. W., Yi, B., \& Lin, J. B. (2013). Media coverage, board structure and CEO compensation: Evidence from Taiwan. Journal of Multinational Financial Management, 23, 434-445. 
Cohen, W. M., \& Levinthal, D. A. (1990). Absorptive capacity: A new perspective on learning and innovation. Administrative Science Quarterly, 128-152.

Core, J. E., Guay, W., \& Larcker, D. F. (2008). The power of the pen and executive compensation. Journal of Financial Economics, 88(1), 1-25.

Daily, C. M., \& Dalton, D.R. (1992). Officer and director stock ownership and firm performance in the publicly trade small corporation. Journal of Business Strategies, 9(2), 101-113.

Darnton, R. (1975). Writing news and telling stories. Daedalus, 104, 175-194.

DiMaggio, P. \& Powell, W. (1983). "The iron cage revisited: Institutional isophomorphism and collective rationality in organizational fields." American Sociological Review, 48, 147-160.

Gamson, J. (1994). Claims to fame: Celebrity in contemporary America. Berkeley and Los Angeles: University of California Press.

Ferster, C. B., and Skinner, B. F. (1957). Schedules of Reinforcement. New York: Appleton-Century-Crofts.

Fox, F. V., \& Staw, B. M. (1979). The trapped administrator: Effects of job insecurity and policy resistance upon commitment to a course of action. Administrative Science Quarterly, 449-471.

Gates, S., Reckers, P., \& Robinson, D. (2009). Media image of the CEO and the impact on auditors' perception of financial reporting reliability and client risk assessments. Advances in Accounting, 25(2), 156-164.

Gilovich, T., Vallone, R., \& Tversky, A. (1985). The hot hand in basketball: On the misperception of random sequences. Cognitive Psychology, 17, 295-314.

Hambrick, D. C. (2007). Upper echelons theory: An update. Academy of Management Review, 32, 334-343.

Hambrick, D. C., \& Mason, P. A. (1984). Upper echelons: The organization as a reflection of its top managers. Academy of Management Review, 9, 193-206.

Hayward, M. L., Rindova, V. P., \& Pollock, T. G. (2004). Believing one's own press: The causes and consequences of CEO celebrity. Strategic Management Journal, $25,637-653$.

Hayward, M. L., \& Hambrick, D. C. (1997). Explaining the premiums paid for large acquisitions: Evidence of CEO hubris. Administrative Science Quarterly, 103127.

Heider, F. (1958). The Psychology of Interpersonal Relations. New York: Wiley.

Hilary, G., \& Menzly, L. (2006). Does past success lead analysts to become overconfident?. Management Science, 52, 489-500. 
Koh, K. (2011). Value or glamour? An empirical investigation of the effect of celebrity CEOs on financial reporting practices and firm performance. Accounting \& Finance, 51, 517-547.

Kernberg, O. F. (1989). The narcissistic personality disorder and the differential diagnosis of antisocial behavior. Psychiatric Clinics of North America, 12, 553570 .

Jensen, M. C., \& Meckling, W. H. (1976). Theory of the firm: Managerial behavior, agency costs and ownership structure. Journal of Financial Economics, 3, 305360.

Leary, M. R., \& Kowalski, R. M. (1990). Impression management: A literature review and two-component model. Psychological Bulletin, 107, 34-47.

Levitt, B., \& March, J. G. (1988). Organizational learning. Annual Review of Sociology, 319-340.

March, J. G. (1991), "Exploration and exploitation in organizational learning," Organizational Science, 2, 71-87.

McCartney, H. P. (1987). Applying fiction conflict situations to analysis of news stories. Journalism \& Mass Communication Quarterly, 64, 163-170.

McGuire, J. W. (1963). Business and society. New York: McGraw-Hill.

McQuail, D. (1985). Sociology of mass communication. Annual Review of Sociology, 93-111.

Meindl, J. R., Ehrlich, S. B., \& Dukerich, J. M. (1985). The romance of leadership. Administrative Science Quarterly, 78-102.

Miller, D. (1991). Stale in the saddle: CEO tenure and the match between organization and environment. Management Science, 37, 34-52.

Nyberg, A. J., Fulmer, I. S., Gerhart, B., \& Carpenter, M. A. (2010). Agency theory revisited: CEO return and shareholder interest alignment. Academy of Management Journal, 53, 1029-1049.

O’Boyle, Jr., E. H., Forsyth, D. R, Banks, G. C., \& McDaniel, M. A. (2012). A metaanalysis of the Dark Triad and work outcomes: A social exchange perspective. Journal of Applied Psychology, 97, 557-579.

Park, D. J., \& Berger, B. K. (2004). The presentation of CEOs in the press, 19902000: Increasing salience, positive valence, and a focus on competency and personal dimensions of image. Journal of Public Relations Research, 16, 93125.

Park, J. H., Kim, C., \& Sung, Y. D. (2014). Whom to dismiss? CEO celebrity and management dismissal. Journal of Business Research, 67, 2346-2355. 
Petrenko, O. V., Aime, F., Ridge, J., \& Hill, A. (2015). Corporate social responsibility or CEO narcissism? CSR motivations and organizational performance. Strategic Management Journal. doi:10.1002/smj.2348

Ranft, A. L., Zinko, R., Ferris, G. R., \& Buckley, M. R. (2006). Marketing the image of management: The costs and benefits of CEO reputation. Organizational Dynamics, 35, 279-290.

Rein, I. J., Kotler, P., \& Stoller, M. R. (1987). High visibility. New York: Dodd, Mead \& Company.

Rindova, V. P., Pollock, T. G., \& Hayward, M. L. (2006). Celebrity firms: The social construction of market popularity. Academy of Management Review, 31, 50-71.

Salancik, G. R., \& Kiesler, C. A. (1971). Behavioral commitment and retention of consistent and inconsistent attitude word-pairs. The Psychology of Commitment.

Sinha, P. N., Inkson, K., \& Barker, J. R. (2012). Committed to a failing strategy: Celebrity CEO, intermediaries, media and stakeholders in a co-created drama. Organization studies, 33, 223-245.

Staw, B. M. (1976). Knee-deep in the big muddy: A study of escalating commitment to a chosen course of action. Organizational Behavior and Human Performance, $16,27-44$.

Staw, B. M. (1981). The escalation of commitment to a course of action. Academy of Management Review, 6, 577-587.

Nimmo, D. D., \& Sanders, K. R. Handbook of Political Communication. Beverly Hills: Sage Publications.

Treadway, D. C., Adams, G. L., Ranft, A. L., \& Ferris, G. R. (2009). A meso level conceptualization of CEO celebrity effectiveness. Leadership Quarterly, 20, 554-570.

Tversky, A., \& Gilovich, T. (1989). The "hot hand": Statistical reality or cognitive illusion?. Chance, 2, 31-34.

Wade, J. B., Porac, J. F., Pollock, T. G., \& Graffin, S. D. (2008). Star CEOs: benefit or burden?. Organizational Dynamics, 37(2), 203-210.

Van Rompay, T. J., Vonk, D. J., \& Fransen, M. L. (2009). The Eye of the Camera Effects of Security Cameras on Prosocial Behavior. Environment and Behavior, 41, 60-74.

Zahra, S.A., \& George, G. (2002). Absorptive capacity: Areview, reconceptualization, and extension. Academy of Management Review, 27, 185-203.

Zajac, E. I., \& Bazerman, M. H. (1991). Blind spots in industry and competitor analysis: Implications of interfirm (mis) perceptions for strategic decisions. Academy of Management Review, 16, 37-56. 


\section{BIOGRAPHICAL SKETCH OF AUTHORS}

Shelby J. Solomon is a Ph.D. candidate at Louisiana State University, studying strategic management and entrepreneurship. Before attending Louisiana State University, Shelby earned a B.A. in economics and an MBA, both from the University of New Mexico. His research interests focus on topics centered on entrepreneurship and critical theory. In addition, he is also interested in strategic decision-making research. Shelby is also active in AOM, SMA, and USASBE.

Josh Bendickson earned his Ph.D. in Strategic Management from Louisiana State University. Josh's research interests include strategic human capital, small business/entrepreneurship, and international strategy and he is a member of multiple professional organizations including the Academy of Management, Southern Management Association, and the United States Association for Small Business and Entrepreneurship, among others. Josh is an assistant professor of management at the University of Louisiana at Lafayette. 